\title{
Some Lessons to be Learned from the Present Inflation
}

\author{
A Speech by DARRYL R. FRANCIS, President, Federal Reserve Bank \\ of St. Louis, to the University of Miami Commercial Bank Forum, \\ Doral Country Club, Miami, Florida, September 24, 1970
}

\section{I} I IS GOOD to have this opportunity to discuss with you some of my views regarding the inflation which has plagued our economy for the past five or six years. It seems important to me that all of us understand current economic stabilization problems and the efforts of our public officials to handle them.

If our economy is ever to contain inflation, we must have leaders who are aware of the causes of inflation, of its costs to our society, and of the difficulties inherent in reducing inflation once it is allowed to ran rampant.

Since late 1964 prices have been rising with increasing rapidity, with effective attempts to control this situation only in the last two years. Now that we have undergone for several years our worst inflation since World War II, it is timely to reflect on this experience and to draw some conclusions. If the obvious lessons of the last six years are remembered in the future, the likelihood of repeating unnecessary mistakes should be reduced considerably. Only by avoiding such mistakes can our economy experience economic growth at a high level of employment with a reasonable stable price level. These, of course, are widely accepted national economic goals.

\section{The Current Inflation}

Before going to the main part of my remarks, let me review the course of the present inflation and steps we have taken to curb it. Our economy had a period of substantial price stability from 1958 to 1964 . During this period the wholesale price index was virtually unchanged, the consumer price index rose about one per cent a year, and the GNP price deflator rose at only a slightly faster rate than consumer prices. Those six years of relatively stable prices marked the end of the inflation generated during World War II and the Korean War. By 1964 we had achieved a high level of resource utilization, and prospects were good for continuing price stability. Our economy was moving into a period when it could be said that the goals of economic stabilization had been essentially achieved.

But, then, from 1964 to just recently, an era of ever more rapidly increasing prices developed. This inflation was caused by growth of total spending for goods and services at an eight per cent annual rate from 1964 to 1968 , or about twice as rapid as our economy's ability to increase the production of goods and services. This excessive expansion in total spending was fostered by very stimulative monetary actions of the Federal Reserve System, supported by the Administration, the Congress, and public opinion. The nation's money stock, except for a brief interlude in 1966 , rose at rates which approximated those prevailing during the World War II and the Korean War inflations.

One of the main reasons for such extremely high rates of monetary growth appears to have been a decision to expand welfare programs and the Vietnam War simultaneously and to finance these increases, in large part, by inflating the monetary system rather than exclusively by taxes or borrowing from the planned saving of the public. These latter two sources of Govemment finance are basically noninflationary, because most of an increase in Government expenditures is then made at the expense of private expenditures. * On the other hand, when increased Government expenditures are accompanied by excessive monetary expansion, there is little, if any, direct reduction in private spending. In fact, there are strong secondary repercussions from such a method of Govemment finance which greatly enlarge spending by business firms and consumers.

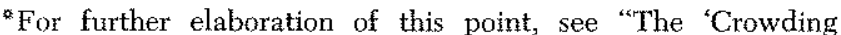
Out of Private Expenditures by Fiscal Policy Actions," on pages $12-24$ of this Review.
} 
Significant actions to curb inflation, either fiscal or monetary, were delayed well into 1968, despite acknowledgment of the existence of a serious inflation and often-expressed desires to do something about it. Then, in mid-1968 a program of reducing the rate of increase in Govermment spending and increasing taxes was adopted with a view to bringing the excessive rate of growth in total spending more into line with growth in potential output of goods and services. However, it was not until the rate of growth in the money stock was reduced markedly in 1969 that the stage was set to bring total spending more in line with growth in our economy's productive potential.

Curbing such a long inllation has proven, once again, to be both slow and costly. Only in recent months has there been any evidence of a slowing in the rate of price increase, and the period is still too short to conclude definitely that there has been a marked waning of inflation. I am confident, though, that if monetary growth is limited to a moderate rate for the next several months, there will be significant, but slow, abatement of inflation. On the cost side of setting the stage for reducing inflation, there has been a slowdown in output of goods and services accompanied by a rise in unemployment. It should be pointed out, however, that the present slowdown has been much less than during any of the other such slowdowns during the past twenty-five years.

\section{Some Lessons}

I turn now to the main theme of this discussion some lessons to be leamed from the present inflation. In developing these lessons, I will point up some of the failures of commonly accepted economic ideas regarding economic stabilization which have been instrumental in permitting our present inflation to develop. By the commonly accepted economic ideas, I mean the form of analysis taught in the majority of undergraduate economics courses for the past twentyfive years. Although most economists have now advanced beyond this rather limited analysis, it still permeates the thinking of the general public, many business and financial leaders, news writers, politicians, and public policymakers.

\section{Inflation a Monetary Phenomenon}

One lesson, and I believe the most important, is that inflation is primarily a monetary phenomenon, whereas the conventional view has placed great stress on Government deficits, union power, and business monopolies as causes of inflation. There is now con- siderable evidence from studies at our Bank and by others that the excessive total spending which led to a high and accelerating rate of price advance was generated, for the most part, during 1964 to 1968 by the exceedingly high rate of monetary expansion of that period.

As I pointed out earlier, rapid growth in Government spending and deficits is not a major source of inflation unless accommodated by growth in the money stock. Likewise, upward pressures on prices from union or business monopoly actions are not likely to initiate a period of inflation unless accompanied by rapidly rising total spending. Such a rise in total spending requires expansive actions on the part of monetary authorities. Thus, the price level effect of often mentioned fiscal and monopoly causes of inflation can be contained if they are not validated by monetary actions which generate a rapid growth in total spending.

\section{Popular Economic Analysis Inadequäe}

Another lesson to be leamed from our recent inflation is that the popular economic analysis of the past quarter century has been ill-equipped to correct inflation. A major aspect of this conventional analysis, as I mentioned earlier, is that the general price level is believed to be only remotely influenced by monetary actions. Instead, in addition to fiscal actions, considerable emphasis is given to controlling undesired price level movements by measures to reduce monopoly power or by exertion of Government pressure, such as guidelines, to induce those who set prices to act in a manner consistent with national objectives. This view, which was developed in large part from the experience of the Great Depression of the 1930's, is still prevalent in the economic theory which underlies much of popular thought regarding economic stabilization. By being developed within such a depression orientation, this body of theory is not particularly useful, in my opinion, in developing programs to cope with an inflationary situation such as we have experienced since 1964. Also, reliance on such devices as the wage-price guidelines during the 1960's became a substitute for sound stabilization policy, and thereby, contributed to the emergence of inflation.

\section{Roles of Monetary and Fiscal Actions}

A further lesson from our experience of recent years is that monetary actions rather than fiscal actions should be given the major role for stabilizing 
the conomy. Unif recently, fiscal actions in the form of Govermment spending and taxing programs have been given the main emphasis in economic stablization efforts to the virtual exclusion of monetary actions. Such a development was an outgrowth of conventional economics, which for the past thirty-five years has taught that Federal Reserve actions exercise little infuence on total demand for goods and services. According to this conventional thought, changes in the money stock bring about changes in market interest rates, while total demand is little influenced by interest rate movements. Consequently, monetary actions have been thought to be of little use in any program of economic stabilization. On the other hand, increased Government expenditures are viewed as adding directly to total demand, and tax reductions are thought to add to disposable income which subsequently is used to purchase goods and services. Consequently, this view has argued that fiscal actions have an immediate and powerful influence on total spending.

This conventional analysis, possibly because of its simplicity which helps in the teaching of under. graduate economics, has received wide acceptance as evidenced in discussions of economic stabilization by the general public, in the press, in the Congress, and even in some of the Reports of the Council of Economic Advisers during the mid-1960s. It should be pointed ont that this view of the influence of fiscal actions does not take into consideration the importance of choice among the three alternative means of financing Government expenditures - taxes, borrowing from the public, and monetary expansion.

At the St. Louis Federal Reserve Bank we have reported several studies regarding the relative importance of monetary and fiscal actions for economic stabilization. Our empirical studies for the United States economy from 1919 to 1969 and for several foreign countries in the post-World War II period support the view that monetary actions, measured by changes in the money stock, should receive the main emphasis in economic stabilization, not fiscal actions.

The accelerating infation of the last half of the 1960's can be attributed, in large part to the great emphasis given to fised actions and the downgrading of monetary infuence. Monetary authorites did not reduce the rapid rate of monetary expansion during a large part of that period because there was a desire to let fiscal actions curb inflation and a belief by some that only fiscal actions would be effective. Then, when restrictive iscal actions were taken in mid-1968 - the surtax and slower increases in Govemment spending - many economists, on the basis of prevalent theories, predicted "fiscal over-kill" by early 1960 . In response to such predictions, monetary azthorilies engaged in even more expansionary actions in the last half of 1969 . Continuation of accelerating infation after fiscal actions had been expected to provide a quick cooling of the infationary fires should bum firmly into our memonies the lesson that monetary actions are more effective than fiscal actions in promoting eeonomic stability.

But I do not want there to be any misunderstanding regarding our view concerning fiscal actions. Some have interpreted us as saying that Govemment spending and taxing have no intuence on the course of the economy, but this is not the case. Our research indicates that acclerations and decelerations in the rate of increase in Government spending, even if there is no accommodating change in money, cause corresponding shortrun changes in total spending. Also, financing of large Govemment deficits has in the past caused the Federal heserve to expand the money stock at excessive rates. This was one reason for rapid monetary growth in 1967 and 1968. Finally, Govern ment spending and taxing programs, insofar is they affect the amount of resources allocated to private investment and to Govermment outlays of a similar nature, may have a signifcant infuence on long-run economic growth.

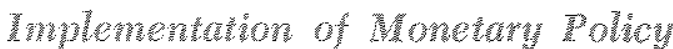

An additional lesson we have learned from our present inflation is that the usual method of carrying out monetary policy in the 1950's and 1960's was frulty. Although stated monetary policy was to control inflation, the method used for implementing this policy actually contributed to the inflation rather than to its control.

Discretionary monetary policy was renstated in 1951, after its suspension during World War II and ap through the early part of the Korean War. The purpose of the 1951 change was to permit monekary authorities to fight the inflation of the Korean War. In conducting is monetary policy responsibilities since then, the Federal Open Market Committee until very recently bas relied largely on measures of money market conditions as guides to its operations. I am sure that most of you are familiar with the view that falling interest rates or rising free reserves indicate easy monetary actions, while tight actions are indicated by rising interest rates or falling free reserves. 
Such at view was in general agreement with the widely held belief that monetary actions work primarly through changes in market interest rates. It also was in agreement with the view that the Federal Reserve has great ability to "se?" market interest mates. Recent research and experience, however, have tended to reject these propositions. For example, rapid monetary expansion, such as in 1967 and 1968, stimulates total spending and thereby generates rapidly growing demand for credit and rising interest rates:

By using market interest rates to indicate the thrust of monetary actions, many pubio policymakers conchuded that despite very rapid monetary growth, rising interest rates were evidence of monetary restraint durng 1967 and 1968. In fact, there was a belief by many that the extont of the increase in market interest rates was too great because of the dislocations which occurred in the savings and housing industries. There was a desire to hold back the extent of interest rate increases, but attempts to do so required injections of bank reserves which contributed to a rapid growth in the money stock. This, in turn, fostered excessive total demand and fed further the fres of inflation. In retrospect, it is now apparent that the traditional reliance on such measures of money maket conditions as market interest rates contributed to our present inflation.

Sound conomic stabilization requires guides to the thrust of monetary actions other than money maket conditions. Recent experience demonstrates that tse of a monetary aggregate, such as the money stock, would have produced far better results than we got during the last half of the $1960^{\circ}$ s. Excessive total spending followed the very rapid rates of nonetary expansion from early 1965 to early 1966 and during 1967 and 1968. But when money ceased to grow in the last eight months of 1966 and grew only slowly in 1960 , total spending slowed markedly after a short lag. Conclusions I have advanced from this casual analysis have been supported by a growing body of empirical research.

\section{Importance of price Anthobations}

A further lesson concems the importance of price anticipations in the infationary process and in the curbing of inflation. As I mentioned ealier, nuch of economic theory unon which recommendations for stabilization actions during the 1960 s rested did not give adequate considuration to the basic forces influencing the price level. Little consideration was given to the well-known thet that consumers, businessmen and labor unions do take into consideration anticipated price level changes when making decisions to purchase goods and services in the present and when negotiating contracts for the future. Once growh of total demand exeeds growth of potential ontput and infation has been underway for a period of time, these decision-makers tend to extrapolate the past trend of prices into the future in an attempt to protect their positions from the ravages of inflation.

This process provides a momentum to inflation which causes prices to continue to rise. This infla tionary momentam may carry on well after public policy steps have been taken to bring total demmat growth into line with potental ouput growth. Such a development has been seen in recent experience in which, after a year or so of reduced rate of growth of total spending, the price level has continued to rise rapidly.

Another manifestation of inflationary expectations during the past several years has appeared in financial markets. There is a considerable body of economic theory which holds that maket interest rates are greatly infuenced by expected price level movements. This proposition was not incorporated into the conventional theory underlying stabilization efforts of the 1960 's. We who maintain that market interest rate movements reflect inflationary expectations argue that when prices are expected to rise, borrowers are willing to pay higher interest rates because they will pay back with depreciated dollars. In addition, any delay in making purchases using borrowed funds will result in high costs in the future. We also argue that lenders will ask for higher interest rates in order to protect the purchasing power of their funds. Thus, both demand and supply forces during a period of inflation lead to higher and higher interest rates.

Many who followed conventional views were at a loss to explain the marked rise in interest rates from 1965 to 1968 at a time when the money stock was rising rapidly. At the St. Louis Federal Reserve Bank we have reported empirical evidence that inflation caused almost all of this increase in market interest rates. The recent experience demonstrates that rapid monetary expansion produces high, not low, interest rates. The truth is the reverse of conventional wisdom regarding interest rate movements.

This lesson leads to the conclusion that the theoretical foundation of economic stabilization must give adequate recognition to the pervasive influence of 
price level expectations. Not to do so, would be to repeat the mistakes of the past. I believe that this lesson has already shown up in the expressed views of many policymakers, but there has been little evidence that it has been leamed by the general public, by the Congress, or by economic commentators in the news media and market news letters.

\section{Regulation $Q$ and Control of Inflation}

Another lesson from the recent experience is that ceilings on interest rates paid by commercial banks on time deposits, set by the Federa Reserve under Regulation Q, are not an effective device for slowing growth in total spending, as many maintained in the late $1960^{\circ}$ s. Instead, such ceilings merely create inefficiencies in our financial markets. Commercial bankers are well aware of the rechamneling of loan funds away from banks and into such markets as the one for commercial paper when free market interest rates exceed Regulation Q ceiling rates.

Some have argued that since banks can make fewer loans under such circumstances, total spending will be restrained. The fact of the matter is that while spending by potential bank borrowers may be reduced, spending by those who have access to the money markets will rise by about the same amount. As a result, total spending is little affected by manipulation of Regulation $Q$ interest rate ceilings.

These ceiling rates on time deposits, however, have led to inefficiencies in the flow of funds and in utilization of real resources in recent years. As a result of $Q$, customary movements of loan funds from one corporation to another through commercial bank channels flow instead through the more direct commercial paper market or through the less direct and less efficient Euro-dollar market. Such rechanneling of loan funds reduces the size of the commercial banking system relative to the total market for funds, a process which is not essential for stabilization policy. Other interest rate ceilings, including state usury laws and ceilings set on funds raised by savings and loan associations and mutual savings banks, also lead to less efficient channeling of funds and use of resources.

\section{Costs of Adpating to Inflation}

Another lesson from recent experience is that there are great costs of adjusting to accelerating inflation. Everyone is familiar with such losses from inflation as reduced purchasing power of fixed income groups and of holders of wealth in the form of fixed money claims. It is true that if inflation is anticipated correctly, a large number of individuals can adjust their contracts and wealth holdings so as to avoid most of the effects of rising prices. And, in recent years Congress has kept Social Security benefits more or less abreast of the price increase, thereby helping to maintain the purchasing power of a large number of retired persons.

However, when the rate of inflation is changing rapidly, and holders of wealth attempt to adjust their holdings, there are losses in addition to that from reduced purchasing power. For example, the great drop in the bond market during our present inflation and the recent bear stock market are partly a consequence of attempts of investors to adjust to accelerating inflation. This recent experience demonstrates that even the stock market may not be a very good hedge against inflation when the rate of price advance is accelerating.

There are also considerable losses to the whole economy resulting from the adjustment process which accompanies accelerations in the rate of price advance. Inefficiencies develop in product, resource, and financial markets in the process of adjusting prices and contracts to rising prices. Normal business transactions become more difficult. For instance, we have reports that some business firms in recent years quoted list prices only on a day-to-day basis. Their salesmen were required to contact the home office before any price could be quoted. Labor contract negotiations become more difficult to settle. In financial markets investors have to pay greater attention to ascertaining the impact of inflation on their portfolios and on alternative outlets for their funds.

\section{Costs of Cubing Infation}

A final lesson is that curbing a rapid, prolonged and accelerating inflation is a slow and difficult process, and is not without considerable costs. As I mentioned earlier, anticipations of price increases provide a powerful momentum to inflation. Such anticipations respond slowly to actual price movements and are not reduced until the rate of inflation has actually subsided for some time. As a result of this slow process of reducing anticipated rates of price increase, the general price level continues to rise rapidly for some time after restraint is applied to growth in total spending. 
Many have been surprised and disappointed that restraint of the past two years has not produced greater results in terms of the price level. Some have even expressed despair at ever seeing relative price stability again. It should be pointed out, however, that inflation was permitted to develop for almost five years before effective restraint was applied. By then, inflation was moving along under its own momentum, and only moderate restraint was applied. It should, therefore, not be surprising that five years of inflation cannot be eliminated in a short period of time. Moreover, it shottd be remembered that the inflations of World War II and the Korean War were not curbed until the late $1950^{\circ}$ s and that much greater restraint was applied in that effort.

There is also considerable cost in eliminating inflation. With restricted growth in total spending and with prices continuing to rise for some time, output of goods and services stagnates or is reduced. As a consequence, there is a loss of jobs and income to many individuals and a loss of goods and services to the whole of our society. Labor strife is accentuated, as we now see, when unions attempt to catch up with inflation and to anticipate further inflation at a time of declining corporate profits.

\section{Conclusions}

Let me now draw a few general conclusions from this discussion of our recent experience. Inflation, because of the many problems and costs it creates, should never be permitted to start. This may seem obvious and trivial, but many have argued that these costs are small compared to alleged large gains flowing from a high level of employment. Our research indicates, however, that inflation is not required for our economy to have a high level of employment.

Another conclusion is that the main body of economic thought of the 1950's and the 1960's has not proven very useful in handling economic stabilization problems. In fact, there is considerable evidence that reliance on this body of thought contributed greatly to the present inflation - both as a cause of rapid price level advances and as a hindrance to their control.

Finally, monetary policy has a major responsibility for promoting price level stability. If such policy is to be applied in an effective manner, the public, the Congress, the Administration, and the Federal Reserve should reflect on the lessons to be learned from the experience of the past six years.

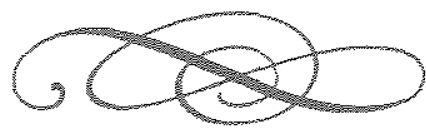

